\title{
Livestock Feed Processing and Storage Mechanizims in Bench Maji, Sheka Ad Kaffa Zones, South West Ethiopia
}

Matawork Gobena Milkias ( $\square$ mataworkmilkias@gmail.com )

Mizan-Tepi University https://orcid.org/0000-0001-8366-2437

Wondimu Teka Woyamo

Wolaita Sodo University

Dessalegn Genzabu Genzabu

Aksum University

Research Article

Keywords: Livestock, Storage, Treatment, Kaffa, Sheka, Bench Sheko

Posted Date: January 6th, 2022

DOI: https://doi.org/10.21203/rs.3.rs-1147870/v1

License: (9) This work is licensed under a Creative Commons Attribution 4.0 International License. Read Full License 


\section{Abstract}

This study was conducted in Kaffa, Bench Maji and Sheka zones with the objective of assessing livestock feed processing and storage mechanisms in South West Ethiopia. Purposive sampling technique was used to select study districts based on livestock population, accessibility and availability of feed resources. A total of 384 households having a minimum one hectare of land and livestock were randomly selected for interview. The mean total number of cattle in the study area was $8.48 \pm 6.79$ per households. Majority of the respondents could not practice livestock feed processing and storage mechanisms in dry and wet season in the study area. The bases for feed provision for livestock in the study area were production level, work load and availability of feed ingredients. Different plants parts were used for livestock to increase milk yield, to improve growth rate and to treat diseases. Livestock production was lowest in dry season due to lack of feed shortage in the dry season. Due to this conclusion, government office should give training how to process and store feeds for dry season.

\section{Introduction}

\subsection{Background}

Ethiopia has the largest livestock population in Africa. Despite the highest population, the productivity of Ethiopian livestock is low, and compared to its potential, the direct contribution to the national economy is limited (Belay et al., 2013). The productivity of the sector is low mainly due to factors such as poor genetic makeup of local animals, poor nutrition and poor veterinary care among which poor nutrition is the major limiting factor (Yeshitila et al., 2008). Feed is the most important input in livestock production and its adequate supply throughout the year is an essential prerequisite for any substantial and sustained expansion in livestock production (Samuel et al., 2008). These feed resources can be classified as natural pasture, crop residue, improved pasture and forage and agro industrial by-products of which the first two contribute the largest share (Tolera et al., 2012).

Green pasture (55.2\%) and crop residues (30.8\%) are the main feed types available in the country (CSA, 2020a). The available feed resources in the mixed crop-livestock production areas are natural pastures, crop residues, and to a lesser extent, improved forage, concentrates, and nonconventional feeds. Natural pasture is the primary feed source for livestock and is abundant during the rainy season. In some areas, it is harvested during wet seasons and conserved as hay for dry seasons (Duressa et al., 2014; Feyissa et al., 2014; Geleti et al., 2014b; Abate et al., 2012; Management Entity, 2021). The role of natural pasture grazing as a major livestock feed resource is diminishing from time to time due to shrinking grazing land size (Yayneshet, 2010). In highlands of Ethiopia, the annual DM production could satisfy only two-third of the total DM requirements of the livestock due to this, during the dry season animals lose their condition which is an indicator of feed shortage and suggests that livestock production and productivity are constrained by feed scarcity (Funte et al., 2010).

A basic shortcoming of the natural grasslands as a source of feed for ruminant livestock is their low production of dry matter due to a combination of the negative effects of inadequate rainfall and soil nutrients. The seasonality of plant growth, which is a reflection of the annual rainfall distribution pattern, further restricts the availability of herbage for the grazing animal to four or five months of the wet season over most of the natural grasslands and the low quality of the herbage is another shortcoming of natural grassland (Ulfina et al., 2013).

Various constrain limits the production of the livestock of Ethiopia among which feed resource related problems are the major one (MOA, 2013). Lack of comprehensive information on regional feed resources, indigenous forage species and feeding systems is one of the important aspects of this issue. Treatment options to achieve optimum utilization or strategic supplementation of crop residues and non-conventional feed resources is not adequately studied and promoted. Feeding guidelines for the different classes of animals and production systems based on available feed resources is limited. Information on nutritional quality of major feed resources is limited (Jimma et al., 2016). This research might provide detailed scientific document to researchers and brief versatile information to farmers, animal science teachers, students, young entrepreneurs and technicians how to improve livestock productivity. This is the reason, the research was aimed to assess livestock feed processing and storage strategies in Kaffa, Sheka and Bench Maji zones of south-western Ethiopia with the following specific objectives.

- To assess the livestock feed processing mechanisms in the study area

Page 2/10 
- To assess livestock feed storage systems practiced in the study area

- To assess livestock feed preparing systems in the study area

\section{Materials And Methods}

\subsection{Description of Study Area}

This study was conducted in three zones of SNNPR namely; Kaffa, Sheka and Bench Maji zone. The administrative center of Bench Maji zone is Mizan-Teferi which is found at distance about $561 \mathrm{~km}$ from Addis Ababa and $830 \mathrm{~km}$ from the regional capital Hawassa. Kaffa is bordered on the south by Debub Omo, on the southwest by Bench Maji, on the west by Sheka, on the north by the Oromia Region, and on the east by Konta. The administrative center of Kaffa is Bonga. Sheka is bordered on the south by Bench Maji, on the west by the Gambela Region, on the north by the Oromia Region, and on the east by Kaffa. The administrative center of Sheka is Masha. Sheka is the western part of former Kaficho Shekicho Zone.

\subsection{Sample Size and Sampling Techniques}

This study was conducted in Kaffa, Sheka and Bench Maji Zones of South Western Ethiopia. The study Districts were purposively selected based on livestock population, accessibility and availability of feed resources. From three Zones, nine potential Districts (three from each zone) were selected based on the information obtained from livestock and fishery development offices in each Zone; 27 rural kebeles (three from each District) were purposively selected on the basis of population of livestock and feed resource availability. Then, a total of 384 households were randomly selected from three zones. The required total number of respondents determined by using the formula developed by Cochran (1963) for infinite population (infinite population $\geq 50,000$ ).

$$
\mathbf{n}=\frac{\left(2 \frac{\underline{a}}{2}\right)^{2} p(1-p)}{e^{2}} \quad \mathbf{n}=\frac{(196)^{2} 0.5(1-0.5)}{(0.05)^{2}}=\mathbf{3 8 4}
$$

\section{Where $\mathrm{n}=$ required sample size}

$Z^{2}=$ is the abscissa of the normal curve that cuts off an area at the tails $(1-a)(95 \%=1.96)$

$\mathrm{e}=$ is the margin of error (eg. $\pm 0.05 \%$ margin of error for confidence level of $95 \%$ )

$p=$ is the degree of variability in the attributes being measured refers to the distribution of attribute in the population set to the most conservative sample size, $p=0.5$ and $q=1-p=0.5$

The numbers of respondents per single selected kebele determined by proportionate sampling technique as follows;

$$
W=[A / B] \times n \text {; Where; }
$$

$A=$ Total number of households living per a single selected kebele

$B=$ Total sum of households living in all selected sample kebeles

$\mathrm{n}=$ the total required calculated sample size.

\subsection{Method of Data Collection}

Survey data were conducted to gather information about the livestock feed processing and storage mechanisms in particular zone or district by using a semi-structured questionnaire, observation and interview. The interviews were conducted at farmer's house with the aid of data collector in the study districts. Information on the socio-economic characteristics of the households (such as sex, age, family size, educational level, number of livestock kept, feed processing, feed storage, etc.) were also collected. Secondary data were obtained from Zonal and District livestock and fishery development offices, books, internet and others.

\subsection{Data Analysis}


The collected qualitative data were analyzed by using SPSS version 21 (SPPSS, 2013) software program. This was also employed for descriptive data, which included frequencies, percentages, means and standard errors in the process of describing feed ingredients. The means of quantitative data between study sites were compared by employing One-way ANOVA in SPSS. The differences between means were declared significant at $P<0.05$. Tukey test was made for mean separation, if there is significant deference.

\section{Results And Discussions}

\subsection{Socio-Economic Characteristics of the Respondents 3.1.1. Household characteristics}

Household characteristics of the respondents in the study area were shown in Table-1. In Sheka zone $91.3 \%$ of respondents were male and $8.7 \%$ were female. In Kaffa zone $89.6 \%$ of respondents were male and the remaining $10.4 \%$ were female. Also in Bench Maji zone $94.7 \%$ of the respondents were male and the remaining $5.3 \%$ were female households (Table 1 ). The results of the current work differ from the report of Azage (2004) who reported 33\% female headed households and 67\% male headed household livestock keepers in Addis Ababa. This result also disagrees with the finding of Endale (2015) in which about $79 \%$ of the respondents were male and 21\% female headed households in Meta Robi District of West Shewa.

The marital status in the study area indicated that $96 \%, 91.2 \%$ and $91 \%$ of interviewed respondents were married in Sheka, Kaffa and Bench Maji zone, respectively. The remaining respondents were single, divorced and widow in the study area.

Most of the respondents in the study area were in primary education level followed by illiterate, secondary and higher education level which was shown in Table 1. From the interviewed respondents $46.8 \%, 51.2 \%$ and $55.6 \%$ were in primary education level in Sheka, Kaffa and Bench Maji zone, respectively. This result disagrees to Duguma and Janssens (2016) report in which 20.4, 11.1, $21.4,35.5$ and $7.4 \%$ of the interviewed farmers had primary, junior secondary, senior secondary, college and university education in Jimma town, respectively.

Table 1

Demographic characteristics of the respondents

\begin{tabular}{|lllll|}
\hline Characters & \multicolumn{4}{l}{ Zones (Frequency/percent) } \\
\cline { 2 - 5 } & Sheka & Kaffa & Bench Maji & Zonal average \\
\hline Sex 0 & & & & \\
\hline Male & $115(91.3)$ & $112(89.6)$ & $126(94.7)$ & $353(91.9)$ \\
\hline Female & $11(8.7)$ & $13(10.4)$ & $7(5.3)$ & $31(8.1)$ \\
\hline Marital status & & & & \\
\hline Married & $121(96)$ & $114(91.2)$ & $121(91)$ & $356(92.7)$ \\
\hline Single & $2(1.6)$ & $4(3.2)$ & $7(5.3)$ & $13(3.4)$ \\
\hline Divorced & $1(0.8)$ & $5(4.0)$ & $5(3.8)$ & $11(2.9)$ \\
\hline Widow & $2(1.6)$ & $2(1.6)$ & - & $4(1.0)$ \\
\hline Education level & & & & \\
\hline Illiterate & $39(31)$ & $40(32)$ & $26(19.5)$ & $105(27.3)$ \\
\hline Primary education & $59(46.8)$ & $64(51.2)$ & $74(55.6)$ & $197(51.3)$ \\
\hline Secondary education & $22(17.5)$ & $19(15.2)$ & $23(17.3)$ & $64(16.7)$ \\
\hline Higher education & $6(4.8)$ & $2(1.6)$ & $10(7.5)$ & $18(4.7)$ \\
\hline
\end{tabular}




\subsubsection{Landholding and land use pattern of the households}

The mean land holding per household, crop land, pasture land, cash crop and fruit land, fallow land, forest land and forage land of the study area were shown in Table 2. The men total land coverage of Sheka, Kaffa and Bench Maji zones were 5.834, 4.293 and 3.914 hectares per households, respectively. This result shows highest land coverage than Adugna et al. (2014) report in which the average land owned per household was 3.3, 5.7 and 1.3 ha at Bikila, Arjo Konan Bula and "Anan Robsan" cooperative located in and around Nekemte town in East Wollega Zone of Oromia Regional State of western Ethiopia, respectively. Endale (2015) reported the average total land owned by the households was 3.8 hectares in Meta Robi District of West Shewa zone in Oromia regional state. The average landholding per household in the study area is higher than the national average of 1.18 ha (CSA, 2011). Total landholding of Sheka zone was significantly higher than that of Kaffa and Bench Maji zones.

Table 2

Landholding and land use pattern of the households in the study area

\begin{tabular}{|lllll|}
\hline Land resource & \multicolumn{3}{l}{ Zonal ME \pm SD } & \\
\cline { 2 - 5 } & Sheka & Kaffa & Bench Maji & Mean total \\
\hline Crop land & $1.419 \pm 0.13^{\mathrm{b}}$ & $1.954 \pm 0.13^{\mathrm{a}}$ & $1.665 \pm 0.13^{\mathrm{ab}}$ & $1.678 \pm 0.08$ \\
\hline Pasture land & $2.368 \pm 0.19^{\mathrm{a}}$ & $0.463 \pm 0.19^{\mathrm{b}}$ & $0.409 \pm 0.19^{\mathrm{b}}$ & $1.067 \pm 0.11$ \\
\hline Cash crop and fruit land & $1.514 \pm 0.14^{\mathrm{a}}$ & $1.096 \pm 0.14^{\mathrm{ab}}$ & $0.919 \pm 0.14^{\mathrm{b}}$ & $1.172 \pm 0.08$ \\
\hline Fallow land & $0.150 \pm 0.06^{\mathrm{b}}$ & $0.372 \pm 0.06^{\mathrm{a}}$ & $0.406 \pm 0.06^{\mathrm{a}}$ & $0.311 \pm 0.04$ \\
\hline Forest land & $0.075 \pm 0.02^{\mathrm{b}}$ & $0.167 \pm 0.02^{\mathrm{a}}$ & $0.195 \pm 0.02^{\mathrm{a}}$ & $0.146 \pm 0.01$ \\
\hline Forage land & $0.308 \pm 0.02^{\mathrm{ab}}$ & $0.241 \pm 0.02^{\mathrm{b}}$ & $0.320 \pm 0.02^{\mathrm{a}}$ & $0.291 \pm 0.01$ \\
\hline Total land & $5.834 \pm 0.56^{\mathrm{a}}$ & $4.293 \pm 0.56^{\mathrm{b}}$ & $3.914 \pm 0.56^{\mathrm{b}}$ & $4.680 \pm 056$ \\
\hline
\end{tabular}

There were significant difference on crop land, pasture land, cash crop and fruit land, fallow land, forest and forage land in the study area. The crop land of Sheka, Kaffa and Bench Maji was 1.419, 1.954 and 1.665 hectare, respectively. This result was comparable with Zewdie (2010) finding in which 1.1 hectare of land were allocated for crop production in highlands of Debre Birhan, Sebeta and Jimma.

\subsection{Feed Processing/Treatment Mechanisms}

Different feed processing mechanisms for grains and pulses, green fodders and dry fodders in dry and wet season were shown in Table 3. Around $64.6 \%$ of the respondents in the study area were not used any processing methods for grains and pulses to feed their livestock in different seasons of the year. This might be due to lack of skill and awareness for farmers how to process feeds to feed their livestock. In contrary to this some farmers used different processing techniques such as grinding, milling, soaking in water, cooking and etc. Addisu et al. (2016) stated that chopping, grinding and ensiling with urea are appropriate methods of improving the feed value of crop residues but this mechanisms are not practiced in East Gojjam Zone. 
Table 3

Feed processing mechanisms in the study area

\begin{tabular}{|c|c|c|c|c|c|c|c|c|c|}
\hline \multirow{3}{*}{$\begin{array}{l}\text { Processing } \\
\text { mechanisms }\end{array}$} & \multicolumn{9}{|l|}{ Seasons } \\
\hline & \multicolumn{3}{|l|}{ Dry } & \multicolumn{4}{|l|}{ Wet } & \multicolumn{2}{|c|}{ Overall } \\
\hline & Sheka & Kaffa & Bench Maji & Sheka & Kaffa & & Bench Maji & Dry & Wet \\
\hline \multicolumn{10}{|c|}{ Processing of grains and pulses } \\
\hline No processing & 63.5 & 68.0 & 30.1 & 79.4 & 71.2 & 44.4 & 53.4 & \multicolumn{2}{|c|}{64.6} \\
\hline Grinding & 4.8 & 10.4 & 19.5 & 4.0 & 8.0 & 20.3 & 11.7 & \multicolumn{2}{|c|}{10.9} \\
\hline Milling & 3.2 & 4.8 & 13.5 & 2.4 & 2.4 & 4.5 & 7.3 & \multicolumn{2}{|c|}{3.1} \\
\hline $\begin{array}{l}\text { Soaking in } \\
\text { water }\end{array}$ & 1.6 & 1.6 & 16.5 & - & 4.0 & 4.5 & 6.8 & \multicolumn{2}{|c|}{3.4} \\
\hline Cooking & 1.6 & 0.8 & 6.8 & 0.8 & 2.4 & 7.5 & 3.1 & \multicolumn{2}{|c|}{3.6} \\
\hline $\begin{array}{l}\text { Grinding and } \\
\text { milling }\end{array}$ & 6.3 & 3.2 & 2.3 & 0.8 & 4.0 & 4.5 & 3.9 & \multicolumn{2}{|c|}{3.1} \\
\hline $\begin{array}{l}\text { Grinding, } \\
\text { milling \& } \\
\text { soaking }\end{array}$ & 8.7 & 7.2 & 9.0 & 1.6 & 4.0 & 9.8 & 8.3 & \multicolumn{2}{|c|}{5.2} \\
\hline $\begin{array}{l}\text { Grinding \& } \\
\text { Soaking }\end{array}$ & 10.3 & 4.0 & 2.3 & 9.5 & 4.0 & 4.5 & 5.5 & \multicolumn{2}{|c|}{6.0} \\
\hline \multicolumn{10}{|c|}{ Processing of green fodder } \\
\hline No processing & 72.2 & 55.2 & 27.8 & 72.2 & 60.0 & 55.6 & 51.3 & \multicolumn{2}{|r|}{62.5} \\
\hline Chopping & 15.9 & 16.0 & 57.9 & 19.0 & 28.8 & 32.3 & 30.5 & \multicolumn{2}{|r|}{26.8} \\
\hline Soaking & 5.6 & 14.4 & 7.5 & 2.4 & 3.2 & 2.3 & 9.1 & \multicolumn{2}{|r|}{2.6} \\
\hline $\begin{array}{l}\text { Chopping \& } \\
\text { soaking }\end{array}$ & 5.6 & 14.4 & 6.8 & 6.3 & 8.0 & 9.8 & 8.9 & \multicolumn{2}{|r|}{8.1} \\
\hline \multicolumn{10}{|c|}{ Processing of dry fodder } \\
\hline No processing & 63.5 & 63.2 & 28.6 & 77.8 & 69.6 & \multicolumn{2}{|c|}{47.4} & 51.3 & 64.6 \\
\hline Chopping & 4.8 & 11.2 & 29.3 & 6.3 & 23.2 & \multicolumn{2}{|c|}{44.4} & 15.4 & 25.0 \\
\hline Soaking & 29.4 & 25.6 & 42.1 & 12.7 & 7.2 & \multicolumn{2}{|c|}{8.3} & 32.6 & 9.4 \\
\hline
\end{tabular}

According to current survey about 51.3 and $62.5 \%$ of respondents were not practiced processing of dry fodder in dry and wet season, respectively. Also about 51.3 and $64.6 \%$ of respondents were not practiced processing of green fodder in dry and wet season, respectively. Alemayehu (2005) reported that urea treatment, chopping and mixing with high quality forages can significantly improve the intake and dietary quality of crop residues. The supplementation of treated or untreated low nitrogen containing basal feeds with forage legumes will increase the nitrogen content of the diet, which is likely to increase feed intake and the rate of degradation of the basal diet in the rumen (Topps, 1997). Addisu et al. (2016) stated that using improved forage crops especially leguminous species with crop residues have an advantage of improving quality, availability and intake of the major feed resources in East Gojjam Zone of Amhara Region.

\subsection{Feed Storage Methods}

Different feed storage methods used in the study area were shown in Table 4. According to the current finding majority of the respondents were not practiced storage of grains and pulses. In contrary some respondents practiced storage of grains and pulses in dry and wet season by sun drying, shade drying, by adding preservatives and by using other methods. In Kaffa and Bench Maji around 20 and $29.3 \%$ of respondents in dry season store by drying in sun, respectively. Also $27.2 \%$ of respondents in 
Kaffa and $35.3 \%$ of respondents store feeds by sun drying in wet season. Addisu et al. (2016) stated that collection and storage of crop residues were common but improving utilization efficiency of cereal crop residues through different treatment mechanisms and feed supplementation were not yet practiced and crop residues were not utilized efficiently in East Gojjam.

Table 4

Feed storage methods used in the study area

\begin{tabular}{|c|c|c|c|c|c|c|c|c|}
\hline \multirow[t]{3}{*}{ Storage methods } & \multicolumn{8}{|c|}{ Season (percent) } \\
\hline & \multicolumn{3}{|l|}{ Dry } & \multicolumn{3}{|l|}{ Wet } & \multicolumn{2}{|c|}{ Overall } \\
\hline & Sheka & Kaffa & Bench Maji & Sheka & Kaffa & Bench Maji & Dry & Wet \\
\hline \multicolumn{9}{|c|}{ Storage of grains and pulses } \\
\hline Not practiced & 81.7 & 69.6 & 46.6 & 87.3 & 66.4 & 60.9 & 65.6 & 71.4 \\
\hline By sun drying & 7.1 & 20.0 & 29.3 & 11.1 & 27.2 & 35.3 & 19.0 & 24.7 \\
\hline By shade drying & 0.8 & - & 6.8 & 1.6 & - & 0.8 & 2.6 & 0.8 \\
\hline By adding preservatives & - & 10.4 & 16.5 & - & 6.4 & 3.0 & 9.1 & 3.1 \\
\hline \multicolumn{9}{|c|}{ Containers used to store grains and pulses } \\
\hline Not practiced & 80.2 & 72.8 & 39.1 & 95.2 & 72.0 & 42.9 & 63.5 & 69.5 \\
\hline In clay pot & 8.7 & 16.0 & 32.3 & 4.8 & 12.8 & 13.5 & 19.3 & 10.7 \\
\hline Plastic container & 2.4 & 3.2 & 6.8 & - & 4.8 & 2.3 & 4.2 & 2.3 \\
\hline Metal container & 2.4 & 0.8 & 0.8 & - & 4.9 & 1.5 & 1.3 & 1.8 \\
\hline Wooden container & 6.3 & 6.4 & 20.3 & - & 6.4 & 36.8 & 11.2 & 14.8 \\
\hline \multicolumn{9}{|l|}{ Storage of dry fodders } \\
\hline Not practiced & 84.9 & 75.2 & 50.4 & 70.6 & 73.6 & 64.7 & 69.8 & 69.5 \\
\hline Bale formation & 12.7 & 10.4 & 36.1 & 22.2 & 24.0 & 28.6 & 20.1 & 25.0 \\
\hline Loose & 2.4 & 12.8 & 13.5 & 7.1 & 2.4 & 6.8 & 9.6 & 5.5 \\
\hline
\end{tabular}

Storing livestock feed in different container are not adapted in the study area as shown in Table 4. According to the current result $69.5,10.7,2.3,1.8,14.8$ and $1 \%$ of the respondents were not practiced storing of grains and pules of livestock feed by using clay pot, plastic container, metal container, wooden container and other containers, respectively. Livestock producers practice preparing dry fodders to their animals and uses different storage systems as shown in Table 4 . Around $69.5 \%$ of the respondents were not practiced storage of dry fodder and the remaining 25 and 5.5\% of the respondent practiced storing dry fodder by making bale and loose, respectively.

\subsection{Preparing Feeds for Livestock}

In current finding around $66.4 \%$ of the respondents could not prepare feed for their livestock in Kaffa, Sheka and Bench Maji zones as shown in Table 5.

About 29.9 and $3.6 \%$ of the respondents were preparing livestock feed by their own mechanism and purchase from market, respectively. This might be due to lack of awareness and lack of knowledge of farmers about how to prepare feeds for livestock which is important in improving livestock productivity.

For livestock production different labors were used for different activities that done in the house hold level. About $91.9 \%$ of the respondents used family labor to feed, to clean house, to water and to do other activities that related with livestock production. 
Feed transportation is one of the tasks in livestock production and management. As indicated in Table $5,84.9 \%$ of the respondents in the study area were transporting inputs to the farm and out puts from the farm by using foots. This result agrees with Endale (2015) finding in West Shewa Zone, the common means of transportations are human power and, donkey and horse's back. Tesfaye and Chairatanayuth (2007) also reported the major problems in collecting and storing crop residues in East shewa zone was transportation problem (35.6\%).

Table 5

Preparing feeds, type of labors and transporting feeds for livestock

\begin{tabular}{|lclll|}
\hline Parameters & \multicolumn{3}{c}{ Zones (Frequency/Percent) } \\
\cline { 2 - 4 } & \multicolumn{1}{c}{ Sheka } & Kaffa & Bench Maji & Zonal average \\
\hline How do you prepare concentrate mixture? & & \\
\hline Not preparation & $95(75.4)$ & $84(67.2)$ & $76(57.1)$ & $255(66.4)$ \\
\hline Prepare by own & $29(23.0)$ & $40(32.0)$ & $46(34.1)$ & $115(29.9)$ \\
\hline Purchase from market & $2(1.6)$ & $1(0.8)$ & $11(8.3)$ & $14(3.6)$ \\
\hline Types of labors used in farm & & & \\
\hline Family labor & $120(95.2)$ & $112(89.6)$ & $121(91.0)$ & $353(91.9)$ \\
\hline Casual labor & $5(4.0)$ & $9(7.2)$ & $8(6.0)$ & $22(5.7)$ \\
\hline Permanent labor & $1(0.8)$ & $4(3.2)$ & $4(3.0)$ & $9(2.3)$ \\
\hline Transporting systems of cut forages/roughages & & \\
\hline On foot & $108(85.7)$ & $102(81.6)$ & $116(87.2)$ & $326(84.9)$ \\
\hline By bajaji & $1(0.8)$ & - & - & $1(0.3)$ \\
\hline By bicycle & - & - & $1(0.8)$ & $1(0.3)$ \\
\hline By public transport & - & - & $1(0.8)$ & $1(0.3)$ \\
\hline By pack animal & $17(13.5)$ & $23(18.4)$ & $15(11.3)$ & $55(14.3)$ \\
\hline
\end{tabular}

Future research directions in livestock feed processing, storing and preparing systems

Current research concluded that feed processing, storage and preparing feeds for livestock were not applied as required for their animals due to different reasons. Depending on this in further the following activities should be conducted by the respective bodies;

- Government as well as Non-government organization work together to create awareness on how to conserve livestock feed in surplus time and importance of conservation

- Majority of the farmers are not practice feed processing and storing for their livestock. So, government and other responsible bodies should encourage farmers though demonstrative training on processing and storing feeds for dry season

\section{Declarations}

Funding: Mizan-Tepi university covered research budget for data collection

Conflicts of interest: Behalf of all authors, corresponding author has no conflicts of interest.

Ethics approval: Not applicable

Consent of participate: Not applicable

Page $8 / 10$ 
Consent for publication: Not applicable

Availability of data and material: Not applicable

Code availability: Not applicable

Authors contributions:

Wondimu Woyamo: Data collection and proposal development

Dr. Desalegn Genzebu: questionnaire preparation and distribution

Acknowledgments

Above all, we would like to thanks our Almighty God for supplying us health, wisdom and strengths in our work and for his perfect protection and guidance of our life.

Next we would like to extend our gratitude to Mizan Tepi University for financial support and Jimma University Animal Nutrition Laboratory for their technical support to analyze the chemical composition of feed samples.

\section{References}

Abate, D., Belete, S., Wegi, T., Usman, S., Wamatu, J., and A. Duncan. 2012. Characterization of the livestock production systems and the potential of feed-based interventions for improving livestock productivity in Sinana district, Bale highlands. International Livestock Research Intitute (ILRI), Nairobi, Kenya.

Addisu Endalew, Firew Tegegne and Getnet Assefa, 2016. Constraints and Opportunities on Production and Utilization of Improved Forages in East Gojjam Zone, Amhara Region, Ethiopia: In the Case of Enebsie Sar Midr District. Journal of Biology, Agriculture and Healthcare, Vol 6 (9).

Adugna Tolera; Fekede Feyissa; Diriba Geleti; Dereje Duressa; Dereje Kebede; Shibru Gurmessa, Wakgari Keba and Alan Duncan, 2014. Assessment of livestock feed production and utilization systems and analysis of feed value chain in Diga District, Ethiopia. DOI: 10.13140/RG.2.1.2127.1446.

Alemayehu Mengistu. 2005. Pasture and Forage Resource Profiles of Ethiopia. pp 19. Ethiopia/FAO. Addis Ababa, Ethiopia.

Azage Tegegn, 2004. Urban livestock production and gender in Addis Ababa, UA-Magazine, 4, 30-31. In: Proceedings of the 14th annual conference of the Ethiopian society of animal production (ESAP). September 5-7, 2006. Addis Ababa, Ethiopia.

Bedasa, E., 2012. Study of Smallholder Farms LivestockFeed Sourcing and Feeding Strategies and their Implication on Livestock Water Productivity in Mixed Crop-Livestock Systems in the Highlands of the Blue Nile Basin, Ethiopia. MSc Thesis Submitted to the School of Graduate Studies. Haramaya University, pp: 139.

Belay, D., Azage, T. and B.P., Hegde., 2013. Smallholder Livestock Production System in Dandi District, Oromia Regional State, Central Ethiopia. Global Veterinarian, 8 (5): 472-479.

CSA (Central Statistical Agency), 2016. Livestock and Livestock Characteristics, Agricultural Sample Survey. Statistical Bulletin. $188 \mathrm{p}$.

CSA (Central Statistical Agency), 2011. Agricultural sample survey. Report on livestock and livestock characteristics (private peasant holdings), vol II. Addis Ababa, Ethiopia, pp 9-26

CSA (Central Statistical Agency), 2018. Federal democratic Republic of Ethiopia. Central Statistical Agency. Statistical Abstract (CSA), Addis Ababa, Ethiopia. 
Duguma Belay and Janssens Geert Paul Jules, 2016. Assessment of feed resources, feeding practices and coping strategies to feed scarcity by smallholder urban dairy producers in Jimma town, Ethiopia. DOI 10.1186/s40064-016-2417-9

Duressa, D., Kenea, D., Keba, W., Desta, Z., Berki, G., Leta, G., and Tolera, A. 2014. Assessment of livestock production system and feed resources availability in three villages of Diga district Ethiopia. ILRI: Addis Ababa, Ethiopia.

Ekwe, K.C., and I. Nwachukwu, 2006. Influence of household factors on the Utilization of Improved Garri Processing Technology in Southeastern Nigeria. Journal of Agricultural. Extension 9:134-141.

Endale Yadessa Dandessa, 2015. Assessment of feed resources and determination of mineral status of livestock feed in Meta Robi District, West Shewa Zone, Oromia Regional State, Ethiopia. An Thesis Submitted to School of Graduate Studies, College of Agriculture And Veterinary Sciences, Department of Animal Sciences: In Partial Fulfillment of the Requirements for the Degree of Master of Science in animal production.

Feyissa, F., Tolera, A., Deresse, A., Assefa, T., Geleti, G., and Alan Duncan, A. 2014. Assessment of livestock feed production and utilization systems and analysis of feed value chain in Jeldu district. ILRI, Addis Ababa, Ethiopia.

Funte, S., Negesse T., Legesse G., 2010. Feed Resources and their Management Systems In Ethiopian Highlands: The Case Of Umbulo Wacho Watershed In Southern Ethiopia. Tropical And Subtropical Agro-ecosystems, 12(1): 47-56.

Geleti, D., Mengistu, S., Mekonnen, A., Tessema, F., Mulugeta, M., Wolde, S., Abiso, T., Tolera, A., and Duncan, A. 2014b. Assessment of livestock feed production and utilization systems and analysis of feed value chain in Lemo district, Ethiopia. ILRI: Addis Ababa, Ethiopia.

Management Entity, 2021. Ethiopia's Livestock Systems: Overview and Areas of Inquiry. Gainesville, FL, USA: Feed the Future Innovation Lab for Livestock Systems.

Ofukou AU, Egho EO, Enujeke E., 2009. Integrated Pest Management (IPM) adoption among farmers in Central Agro-ecological Zone of Delta State, Nigeria. Adv Biol Res 3(1-2):29-33.

Tesfaye, A. and Chairatanayuth, P., 2007: Management and feeding systems of crop residues: the experience of East Shoa Zone, Ethiopia. Livestock Research for Rural Development. http://www.Irrd.org//rrd19/3/tesf19031.htm.

Tolera, A, Yami, A., Alemu, D., 2012. Livestock feed resources in Ethiopia: Challenges, Opportunities and the need for transformation. Ethiopia Animal Feed Industry Association, Addis Ababa, Ethiopia.

Ulfina, G., Habtamu, A., Jiregna, D. and Chala, M., 2013. Utilization of brewer's waste as replacement for maize in the ration of calves. http://www.researchwebpub.org/wjar.

Yayneshet, T., 2010. Ethiopia Sanitary and Phytosanitary Standards and Livestock and Meat Marketing Program (SPS-LMM) Texas A\&M University System:Feed Resources Availability in Tigray Region, northern Ethiopia, for Production of Export Quality Meat and Livestock.

Yeshitila, A., Tessema, Z. and Azage, T., 2008. Availability of livestock feed resources in Alaba District, Southern Ethiopia. In: Proceedings of the $16^{\text {th }}$ annual conference of the Ethiopian Society of Animal Production (ESAP) held in Addis Ababa, Ethiopia, October 8 to 10, 2008. 